\title{
$\mathrm{CO}_{2}$ 辅助老化制备的 $\mathrm{Cu} / \mathrm{ZnO} / \mathrm{Al}_{2} \mathrm{O}_{3}$ 催化剂上 $\mathrm{CO}_{2}$ 加氢制甲醇
}

\author{
王丹君 ${ }^{1,2}$, 陶芙蓉 ${ }^{1,2}$, 赵华华 ${ }^{1,2}$, 宋焕玲 ${ }^{1}$, 丑凌军 ${ }^{1, *}$ \\ 1 中国科学院兰州化学物理研究所羰基合成与选择氧化国家重点实验室, 甘肃兰州 730000 \\ 2 中国科学院研究生院, 北京 100049
}

\begin{abstract}
摘要: 对传统共沉淀法进行改进, 在老化阶段通入 $\mathrm{CO}_{2}$ 促进母液中前驱体物相的转变, 制备了 $\mathrm{Cu} / \mathrm{ZnO} / \mathrm{Al}_{2} \mathrm{O}_{3}$ 催化剂. $\mathrm{N}_{2}$ 吸附、X 射线衍射、场发射扫描电子显微镜、程序升温还原、程序升温分解结果表明,改进共沉淀法制备的催化剂前驱体中碱式硝酸铜 更易转变为碱式碳酸铜, 从而提高了前驱体的稳定性, 并使得焙烧后的催化剂具有较大的比表面积和孔体积及较小的颗粒. 在 $200 \sim 260^{\circ} \mathrm{C}$ 范围内对 $\mathrm{CO}_{2}$ 加氢制甲醇活性测试表明, 改进方法制备的催化剂活性明显优于传统共沉淀法制备的催化剂.
\end{abstract}

关键词: 二氧化碳辅助老化; 铜; 氧化锌; 氧化铝; 二氧化碳加氢; 甲醇合成

中图分类号: O643 文献标识码: A

收稿日期: 2011-04-10. 接受日期: 2011-05-27.

*通讯联系人. 电话: (0931)4968066; 传真: (0931)4968129; 电子信箱: 1jchou@licp.cas.cn

基金来源：国家重点基础研究发展计划 (973 计划, 2011CB201404).

本文的英文电子版(国际版)由Elsevier出版社在ScienceDirect上出版(http://www.sciencedirect.com/science/journal/18722067).

\section{Preparation of $\mathrm{Cu} / \mathrm{ZnO} / \mathrm{Al}_{2} \mathrm{O}_{3}$ Catalyst for $\mathrm{CO}_{2} \mathrm{Hydrogenation}$ to Methanol by $\mathrm{CO}_{2}$ Assisted Aging}

\author{
WANG Danjun ${ }^{1,2}$, TAO Furong ${ }^{1,2}$, ZHAO Huahua ${ }^{1,2}$, SONG Huanling ${ }^{1}$, CHOU Lingjun ${ }^{1, *}$ \\ ${ }^{1}$ State Key Laboratory for Oxo Synthesis and Selective Oxidation, Lanzhou Institute of Chemical Physics, \\ Chinese Academy of Sciences, Lanzhou 730000, Gansu, China \\ ${ }^{2}$ Graduate University of Chinese Academy of Sciences, Beijing 100049, China
}

\begin{abstract}
A} \mathrm{Cu} / \mathrm{ZnO} / \mathrm{Al}_{2} \mathrm{O}_{3}$ catalyst prepared by adding $\mathrm{CO}_{2}$ during the aging step was used for methanol synthesis from $\mathrm{CO}_{2}$ and $\mathrm{H}_{2}$. The catalysts were characterized by $\mathrm{N}_{2}$ adsorption-desorption, X-ray diffraction, field emission scanning electron microscope, temperature-programmed decomposition, and temperature-programmed reduction. The precursor from the modified method with added $\mathrm{CO}_{2}$ had malachite and hydrotalcite-like phases and was more stable than that of the sample without added $\mathrm{CO}_{2}$. After calcination, the modified catalyst had a higher surface area, larger pore volume, and smaller particle size. The modified catalyst gave a higher activity for methanol synthesis from $\mathrm{CO}_{2}$ hydrogenation in the reaction temperature range of $200-260{ }^{\circ} \mathrm{C}$.
\end{abstract}

Key words: carbon dioxide assisted aging; copper; zinc oxide; alumina; hydrogenation of carbon dioxide; methanol synthesis

Received 10 April 2011. Accepted 27 May 2011.

*Corresponding author. Tel: +86-931-4968066; Fax: +86-931-4968129; E-mail: ljchou@licp.cas.cn

This work was supported by the National Basic Research Program of China (973 Program, 2011CB201404).

English edition available online at Elsevier ScienceDirect (http://www.sciencedirect.com/science/journal/18722067).

Copper-based catalysts are used for the synthesis of methanol from syngas at $220-300{ }^{\circ} \mathrm{C}$ and 5-10 MPa [1,2]. However, when the catalyst is used for $\mathrm{CO}_{2}$ hydrogenation, the yield of methanol is much lower than that obtained from syngas under similar reaction conditions [3]. Consequently, there has been much research on the development of improved catalysts [4-8]. It is well-known that a small variation in the preparation process can induce changes in surface structure and bring about different reaction performances. Waller et al. [9] and Millar et al. [10] proposed an 
important variation in the aging period following the initial precipitation. Li and Inui [11] investigated the influence of precipitation conditions on $\mathrm{Cu} / \mathrm{ZnO} / \mathrm{Al}_{2} \mathrm{O}_{3}$ catalysts and found that precipitation performed at $\mathrm{pH}=7$ resulted in a very fine inter-dispersion of $\mathrm{CuO}$ and $\mathrm{ZnO}$ after calcination. They also discussed the reaction mechanism of the co-precipitation based on the work of Vasserman et al. [12]. In this work, we modified the aging method with the adding of $\mathrm{CO}_{2}$ to the mother solution, and investigated the effect on the physiochemical properties and activity for methanol synthesis from $\mathrm{CO}_{2}$ and $\mathrm{H}_{2}$.

\section{Experimental}

\subsection{Catalyst preparation}

The precursors were prepared by the co-precipitation method. An aqueous solution with metal nitrates $(\mathrm{Cu}: \mathrm{Zn}: \mathrm{Al}$ $=6: 3: 1$, molar ratio) and a sodium carbonate solution were added simultaneously with constant stirring to $300 \mathrm{ml}$ of distilled water. The precipitation temperature and $\mathrm{pH}$ were kept at $80^{\circ} \mathrm{C}$ and 8.0 , respectively. After precipitation, the suspension was maintained for $1 \mathrm{~h}$ under stirring with the adding of $\mathrm{CO}_{2}$ to the mother solution. This was followed by filtration and washing with $500 \mathrm{ml}$ warm distilled water for 5 times to remove $\mathrm{NaNO}_{3}$ as much as possible. The precipitate was then dried at $120^{\circ} \mathrm{C}$ overnight and calcined in air at $350{ }^{\circ} \mathrm{C}$ for $6 \mathrm{~h}$. This catalyst was named CZA-1. A referenced catalyst without $\mathrm{CO}_{2}$ assisted aging was named CZA-2.

\subsection{Catalyst characterization}

Images from the field emission scanning electron microscope (FE-SEM) were obtained on a JSM-6701F instrument (JEOL). X-ray diffraction (XRD) measurements were performed on a PANalytica X'pert Pro MPD instrument using $\mathrm{Cu} K_{\alpha}$ radiation in the range of $2 \theta=10^{\circ}-80^{\circ}$ at a rate of $4 \% \mathrm{~min}$ at $40 \mathrm{~mA}$ and $40 \mathrm{kV}$. The surface areas $\left(A_{\mathrm{BET}}\right)$ and pore volume $\left(V_{\mathrm{p}}\right)$ of the calcined samples were calculated from $\mathrm{N}_{2}$ adsorption-desorption data acquired at $-196{ }^{\circ} \mathrm{C}$ on a fully automated ASAP 2010 (Micromeritics) gas adsorption instrument. The powders were first outgassed at $350{ }^{\circ} \mathrm{C}$ to ensure a clean surface. The isotherms were used according to the BET method for surface area calculation and the $\mathrm{BJH}$ method for the pore size distribution.

Temperature-programmed reduction (TPR) experiments were conducted on a AMI-100 instrument. A freshly calcined catalyst sample of about $50 \mathrm{mg}$ (80-100 mesh) was pretreated in a helium flow of $50 \mathrm{ml} / \mathrm{min}$ at $350{ }^{\circ} \mathrm{C}$ for $1 \mathrm{~h}$ and then cooled to room temperature. After that, a reducing gas composed of $5 \% \mathrm{H}_{2}-95 \%$ He was employed at a flow rate of $50 \mathrm{ml} / \mathrm{min}$, and the temperature was ramped from room temperature to $500{ }^{\circ} \mathrm{C}$ at a heating rate of $10{ }^{\circ} \mathrm{C} / \mathrm{min}$. The hydrogen consumption was monitored online by a thermal conductivity detector (TCD). Temperature-programmed decomposition (TPD) was also conducted on the AMI-100 catalyst characterization instrument. The precursor sample of about $10 \mathrm{mg}$ was heated to $700{ }^{\circ} \mathrm{C}$ in helium flow $(80 \mathrm{ml} / \mathrm{min})$ with a heating rate of $10^{\circ} \mathrm{C} / \mathrm{min}$. The evolved gas was monitored online by a quadruple mass spectrometer (MS, Ametek LCD-200).

\subsection{Catalytic activity}

Activity measurements were carried out in a fixed-bed microreactor (i.d. $10 \mathrm{~mm})$. Catalyst (0.5 ml, 20-40 mesh) was loaded in the reactor and the remaining space of the reactor was filled with quartz sand. The temperature was controlled by a thermocouple in contact with the catalyst bed. The pressure in the reactor was maintained by a back pressure regulator and the flow rate of the feed gas was controlled by mass flow controllers. A cold trap was used for the separation of liquid product. Before each test, the catalyst was reduced in situ at $300{ }^{\circ} \mathrm{C}$ for $6 \mathrm{~h}$ in $5 \% \mathrm{H}_{2}-95 \%$ $\mathrm{N}_{2}$ flow $(100 \mathrm{ml} / \mathrm{min})$ at atmospheric pressure. After reduction, the reactor was cooled to the reaction temperature and the feed gas $\left(\mathrm{H}_{2}: \mathrm{CO}_{2}: \mathrm{N}_{2}=75: 25: 1\right)$ was supplied. An online gas chromatograph equipped with a TDX-01 column and a TCD was used for analyzing the outlet gas. The liquid product was analyzed offline by a chromatograph equipped with a flame ionizing detector (FID) and a FFAP column.

\section{Results and discussion}

\subsection{Idea of the modified strategy}

As discussed in the introduction, the aging can remarkably affect the structure and surface morphological properties, which, in turn, affect the activity of the final catalyst. According to Li et al. [11], the following steps (1)-(3) are involved in co-precipitation. During aging, reaction (4) occurs. The release of $\mathrm{OH}^{-}$by reaction (4) causes an increase in the $\mathrm{pH}$ value during aging according to the study of Baltes [13].

$$
\begin{gathered}
\mathrm{Cu}^{2+}+2 \mathrm{OH}^{-} \rightarrow \mathrm{Cu}(\mathrm{OH})_{2}(\mathrm{~s}) \\
3 \mathrm{Cu}(\mathrm{OH})_{2}(\mathrm{~s})+\mathrm{Cu}^{2+}+2 \mathrm{NO}_{3}{ }^{-} \rightarrow \mathrm{Cu}\left(\mathrm{NO}_{3}\right)_{2} \cdot 3 \mathrm{Cu}(\mathrm{OH})_{2}(\mathrm{~s}) \\
\mathrm{Cu}(\mathrm{OH})_{2}+\mathrm{Cu}^{2+}+\mathrm{CO}_{3}{ }^{2-} \rightarrow \mathrm{Cu}_{2}(\mathrm{OH})_{2} \mathrm{CO}_{3}(\mathrm{~s}) \\
\mathrm{Cu}\left(\mathrm{NO}_{3}\right)_{2} \cdot 3 \mathrm{Cu}(\mathrm{OH})_{2}(\mathrm{~s})+2 \mathrm{CO}_{3}{ }^{2-} \rightarrow 2 \mathrm{Cu}_{2}(\mathrm{OH})_{2} \mathrm{CO}_{3}(\mathrm{~s}) \\
+2 \mathrm{OH}^{-}+2 \mathrm{NO}_{3}{ }^{-}
\end{gathered}
$$

The activity results reported by Bems et al. [14] suggested that keeping a constant $\mathrm{pH}$ value during aging, namely, inhibiting the increase of the $\mathrm{pH}$ value by adding a metal nitrate to consume the $\mathrm{OH}^{-}$generated in reaction (4), 
was favorable for the improvement of the physiochemical properties and the catalytic performance. Based on these results, we proposed introducing $\mathrm{CO}_{2}$ during aging to consume $\mathrm{OH}^{-}$by reaction (5), which would facilitate the conversion of $\mathrm{Cu}\left(\mathrm{NO}_{3}\right)_{2} \cdot 3 \mathrm{Cu}(\mathrm{OH})_{2}$ (s) to $\mathrm{Cu}_{2}(\mathrm{OH})_{2} \mathrm{CO}_{3}$ (s).

$$
\begin{gathered}
\mathrm{H}_{2} \mathrm{O}+\mathrm{CO}_{2}(\mathrm{~g}) \rightarrow 2 \mathrm{H}^{+}+\mathrm{CO}_{3}{ }^{2-} \\
\mathrm{OH}^{-}+\mathrm{H}^{+} \rightarrow \mathrm{H}_{2} \mathrm{O}
\end{gathered}
$$

\subsection{Physicochemical characterization}

The surface characterization data confirmed that the total surface area was increased to $110.8 \mathrm{~m}^{2} / \mathrm{g}$ by the $\mathrm{CO}_{2}$ assisted aging method. This was $32 \%$ higher than that of CZA-2 $\left(83.7 \mathrm{~m}^{2} / \mathrm{g}\right)$.

As shown in Fig. 1(a), the CZA-1 catalyst with $\mathrm{CO}_{2}$ assisted aging displayed a narrow pore size distribution and a higher cumulative pore volume (CPV) of ca. $0.357 \mathrm{~cm}^{3} / \mathrm{g}$ with maximal incremental pore volume (IPV) at the pore diameter of $15.3 \mathrm{~nm}$. In contrast, CZA-2 showed a broad pore size distribution (Fig. 1(b)) with maximum IPV at the pore diameter of $30.4 \mathrm{~nm}$, and had a cumulative pore volume of $0.291 \mathrm{~cm}^{3} / \mathrm{g}$.

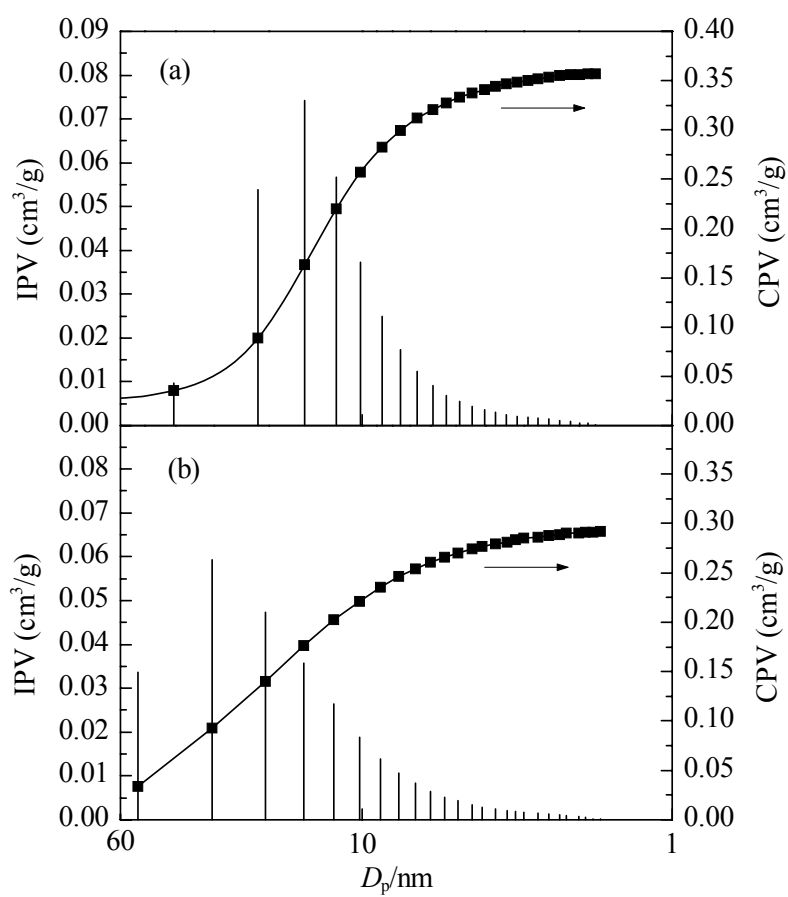

Fig. 1. Pore size distribution of $\mathrm{Cu} / \mathrm{ZnO} / \mathrm{Al}_{2} \mathrm{O}_{3}$ catalysts. (a) $\mathrm{CZA}-1$; (b) CZA-2.

Figure 2 compares the surface morphology of the two catalysts before calcination. With CZA-1 (Fig. 2(a)), most of the hydroxycarbonate were in the form of spheres with particle sizes of 10-50 nm, and numerous pores were observed. With CZA-2 (Fig. 2(b)), some spheres have collapsed and agglomerated into larger irregular aggregates,

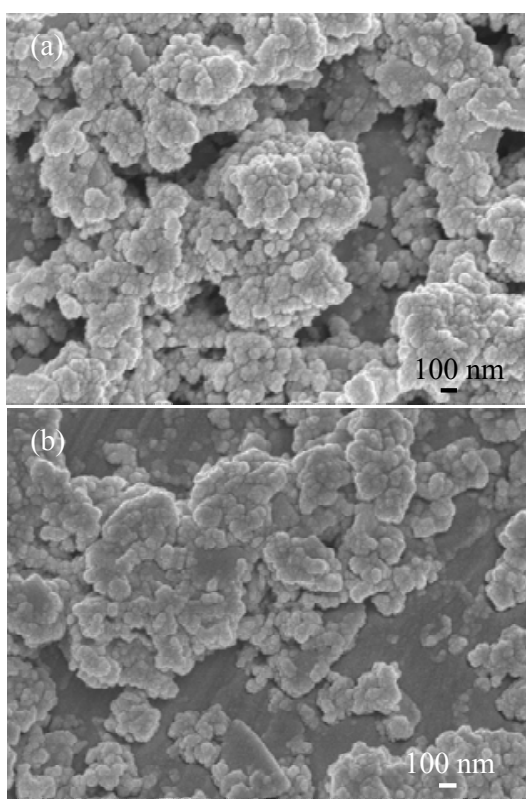

Fig. 2. FE-SEM images of CZA-1 (a) and CZA-2 (b) before calcination.

resulting in less pores. These results are consistent with the surface area and pore volume data.

The XRD patterns of the catalysts before calcination are shown in Fig. 3. The peaks at $2 \theta=14.8^{\circ}, 17.5^{\circ}, 24.1^{\circ}$, $31.5^{\circ}$, and $35.6^{\circ}$ were ascribed to the malachite phase $\left(\mathrm{Cu}_{2} \mathrm{CO}_{3}(\mathrm{OH})_{2}\right)$, and those at $2 \theta=11.9^{\circ}$ and $24.1^{\circ}$ were attributed to the hydrotalcite-like phase $\left((\mathrm{Cu}, \mathrm{Zn})_{6} \mathrm{Al}_{2}(\mathrm{OH})_{16^{-}}\right.$ $\mathrm{CO}_{3} \cdot 4 \mathrm{H}_{2} \mathrm{O}$ ). A different feature was observed with CZA-2. Besides the peak at $2 \theta=11.9^{\circ}$ and $24.1^{\circ}$ from the hydrotalcite-like phase, the peaks at $2 \theta=35.6^{\circ}$ and $38.7^{\circ}$ were due to the $\mathrm{CuO}$ phase. This indicated that the precursors of CZA-2 had decomposed to some extent. By considering the stability of the hydrotalcite-like and malachite phases in $\mathrm{CZA}-1$, it is suggested that the $\mathrm{CuO}$ phase in CZA-2 was

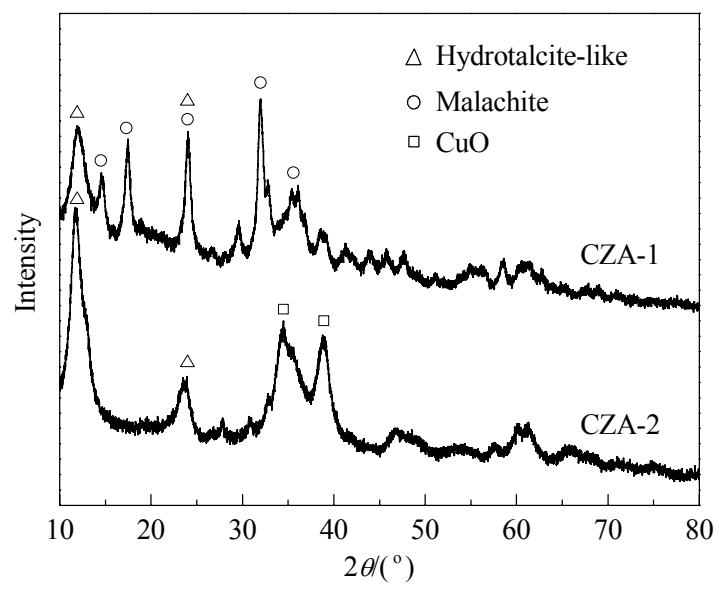

Fig. 3. $\mathrm{XRD}$ patterns of the $\mathrm{Cu} / \mathrm{ZnO} / \mathrm{Al}_{2} \mathrm{O}_{3}$ catalysts before calcination. 
probably from the decomposition of copper hydroxynitrate during the aging process from reactions (7) and (8):

$$
\begin{gathered}
2 \mathrm{Cu}_{2}(\mathrm{OH})_{2} \mathrm{CO}_{3}(\mathrm{~s})+2 \mathrm{OH}^{-}+2 \mathrm{NO}_{3}{ }^{-} \rightarrow \\
\mathrm{Cu}\left(\mathrm{NO}_{3}\right)_{2} \cdot 3 \mathrm{Cu}(\mathrm{OH})_{2}(\mathrm{~s})+2 \mathrm{CO}_{3}{ }^{2-} \\
\mathrm{Cu}\left(\mathrm{NO}_{3}\right)_{2} \cdot 3 \mathrm{Cu}(\mathrm{OH})_{2}(\mathrm{~s})+2 \mathrm{OH}^{-} \rightarrow 4 \mathrm{CuO}+2 \mathrm{NO}_{3}{ }^{-}+4 \mathrm{H}_{2} \mathrm{O}
\end{gathered}
$$

Due to this, the malachite phase in CZA-2 was slowly consumed. However, the introducing of $\mathrm{CO}_{2}$ into the solution promoted reaction (3), which resulted in the formation of the hydroxycarbonate that is more stable under the aging conditions. In addition, the XRD patterns showed that the intensity of its malachite phase peak $\left(2 \theta=11.9^{\circ}\right)$ was much weaker than that with CZA-2, which implied that the crystallites of the malachite phase were smaller than that in CZA-2. This result confirmed that adding $\mathrm{CO}_{2}$ inhibited the crystallites from growing.

After calcination, the hydroxycarbonate phase in the precursor was converted into the metal oxide. As shown in Fig. 4 , the peaks at $2 \theta=35.4^{\circ}, 38.6^{\circ}, 48.5^{\circ}, 58.0^{\circ}, 61.5^{\circ}, 66.0^{\circ}$, and $75.1^{\circ}$ were ascribed to $\mathrm{CuO}$, and that at $2 \theta=32.6^{\circ}$ was due to $\mathrm{ZnO}$. No $\mathrm{Al}$ features was found. The reason was probably because the $\mathrm{Al}$ species existed in highly disordered or amorphous states due to the relatively low calcination temperature $\left(350^{\circ} \mathrm{C}\right)$, or that the crystallites were too small to be detected. The $\mathrm{CuO}$ peaks of CZA-1 were weaker and broader than that of CZA-2, suggesting a smaller average $\mathrm{CuO}$ particle size for CZA-1.

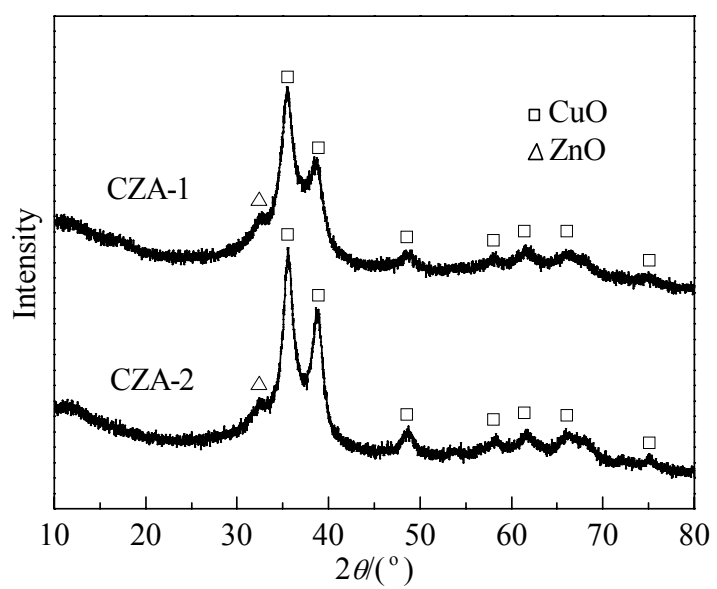

Fig. 4. $\mathrm{XRD}$ patterns of calcined $\mathrm{Cu} / \mathrm{ZnO} / \mathrm{Al}_{2} \mathrm{O}_{3}$ catalysts.

The difference in particle size between CZA-1 and CZA-2 was probably due to the different amounts of $\mathrm{CO}_{2}$ from the decomposition of hydroxycarbonate during the calcination. CZA-1 contained much more hydroxycarbonate while CZA-2 has less because of the decomposition before the calcinations. Thus CZA-1 had much smaller particles than CZA-2. From the TPDE result, shown in Fig. 5, there were three main $\mathrm{CO}_{2}$ release steps from CZA-1 $[15,16]$. The evolution between 140 and $220{ }^{\circ} \mathrm{C}$ was ascribed to the de-

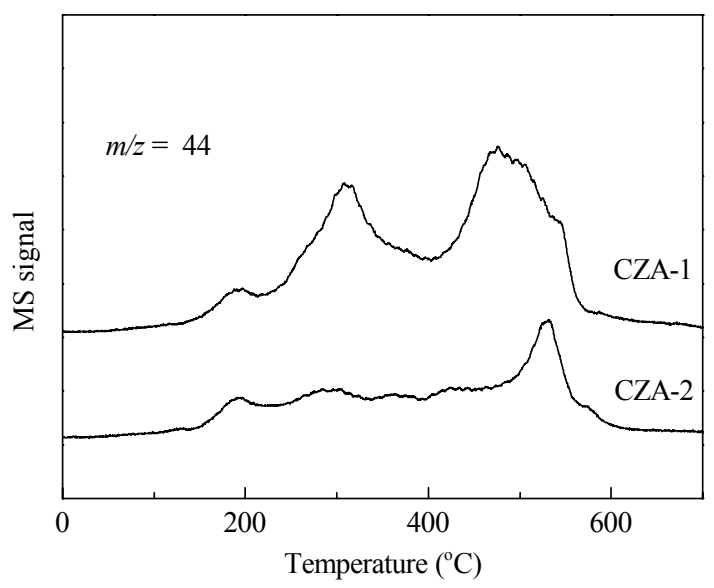

Fig. 5. TPDE profiles of the $\mathrm{Cu} / \mathrm{ZnO} / \mathrm{Al}_{2} \mathrm{O}_{3}$ catalyst precursors.

composition of the hydrotalcite-like precursor. The release of $\mathrm{CO}_{2}$ in the range of $220-400{ }^{\circ} \mathrm{C}$ was attributed to the first decomposition step of hydroxycarbonate and that in the range of $400-600{ }^{\circ} \mathrm{C}$ was ascribed to the second decomposition step of hydroxycarbonate. Clearly, the MS peaks from CZA-1 were much stronger than those of CZA-2, indicating that more $\mathrm{CO}_{2}$ was given off during calcination, which resulted in a more porous CZA-1. This result agreed with the pore volume data from the $\mathrm{N}_{2}$ adsorption-desorption experiment.

TPR experiments are carried out to understand the reduction behavior of the catalysts. As shown in Fig. 6, the two samples displayed reduction profiles characterized by main peaks with temperatures between 230 and $250{ }^{\circ} \mathrm{C}$. These were considerably lower than that of pure bulk $\mathrm{CuO}$ (ca. $300{ }^{\circ} \mathrm{C}$ ) [17]. The onset temperatures for CZA-1 and CZA-2 appeared at $146^{\circ} \mathrm{C}$. A poorly resolved peak was observed for CZA-2 with a shoulder peak $\left(247^{\circ} \mathrm{C}\right)$ on the right side of the maximum $\left(233{ }^{\circ} \mathrm{C}\right)$ while the shape of the peak for CZA-1 $\left(239^{\circ} \mathrm{C}\right)$ was sharper and more symmetrical. These results verified the homogenous distribution of the components for CZA-1.

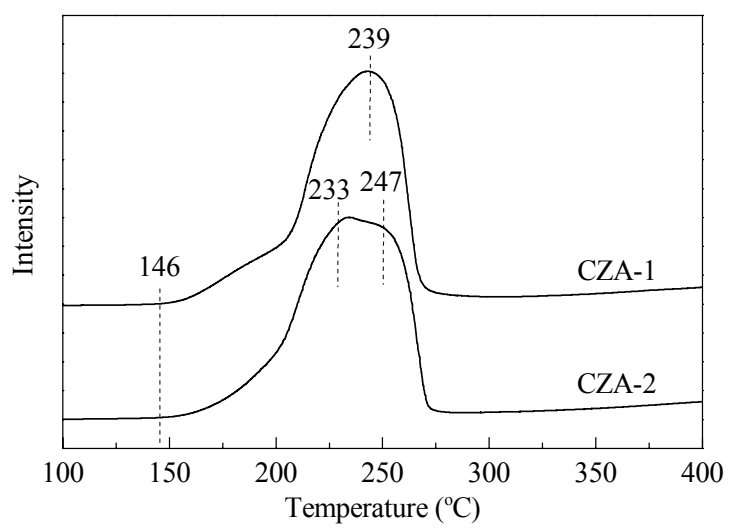

Fig. 6. TPR profiles of the $\mathrm{Cu} / \mathrm{ZnO} / \mathrm{Al}_{2} \mathrm{O}_{3}$ catalysts. 

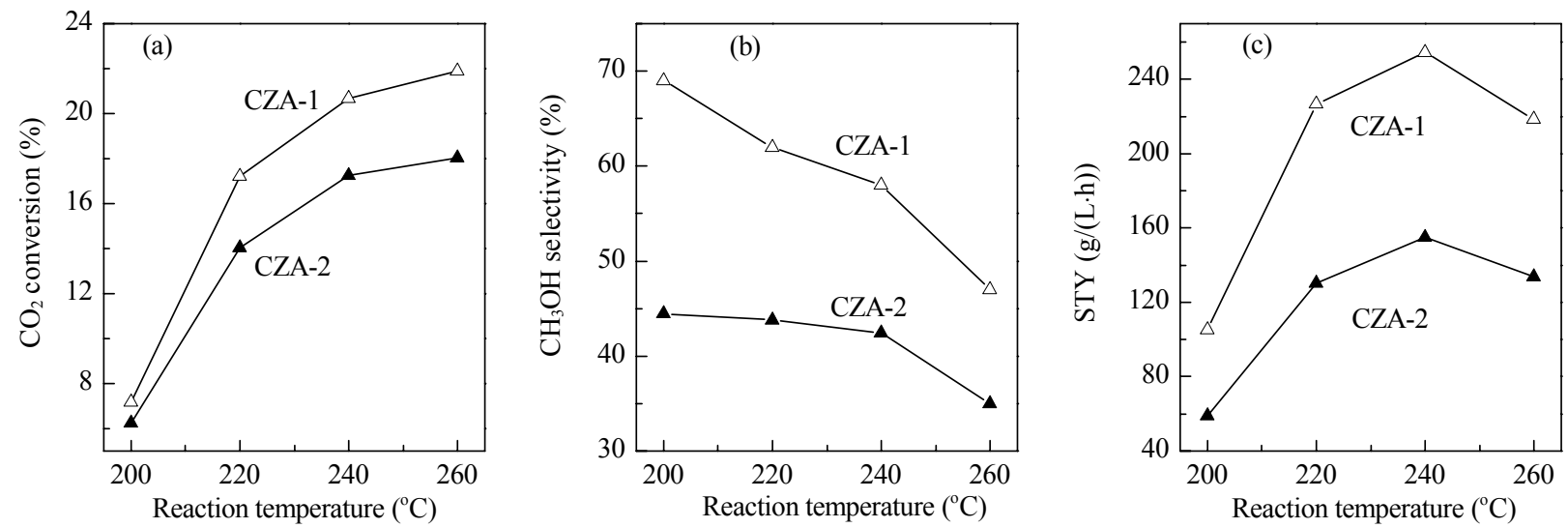

Fig. 7. Catalytic activity of $\mathrm{Cu} / \mathrm{ZnO} / \mathrm{Al}_{2} \mathrm{O}_{3}$ catalysts for $\mathrm{CO}_{2}$ hydrogenation as a function of reaction temperature. (a) $\mathrm{CO}_{2}$ conversion; (b) Methanol selectivity; (c) Space time yield of methanol. Reaction conditions: $\mathrm{SV}=6000 \mathrm{~h}^{-1}, p=5 \mathrm{MPa}, \mathrm{CO}_{2}: \mathrm{H}_{2}: \mathrm{N}_{2}=25: 75: 1$.

\subsection{Catalytic activity}

The hydrogenation of $\mathrm{CO}_{2}$ to methanol was investigated in a steel microreactor. Methanol and carbon monoxide were the major carbon-containing products. The activities of CZA-1 and CZA-2 as a function of reaction temperature in $\mathrm{CO}_{2}$ hydrogenation reaction are shown in Fig. 7. The trend with temperature for the two catalysts was similar. At a low temperature $\left(200{ }^{\circ} \mathrm{C}\right)$, both catalysts showed lower $\mathrm{CO}_{2}$ conversion with a higher methanol selectivity. In the range of $200-260{ }^{\circ} \mathrm{C}$, with the increase of temperature, the conversion of $\mathrm{CO}_{2}$ increased while the selectivity for methanol decreased. At the same time, the space time yield (STY) of methanol increased with the increase of temperature in the range of $200-240{ }^{\circ} \mathrm{C}$ due to the increasing conversion. However, further temperature increase led to the decline of the yield of methanol due to a much decreased methanol selectivity. The highest STY was obtained at $240{ }^{\circ} \mathrm{C}$ and was $254 \mathrm{~g} /(\mathrm{L} \cdot \mathrm{h})$ for CZA-1 and $155 \mathrm{~g} /(\mathrm{L} \cdot \mathrm{h})$ for CZA-2. The activity of CZA-1 which was prepared by $\mathrm{CO}_{2}$ assisted aging was much higher than that of CZA-2.

\section{Conclusions}

To improve the catalyst for $\mathrm{CO}_{2}$ hydrogenation, we modified the aging during the preparation by adding $\mathrm{CO}_{2}$ into the mother solution. $\mathrm{CO}_{3}{ }^{2-}$ from dissolved $\mathrm{CO}_{2}$ promoted the conversion of hydroxynitrate to hydroxycarbonate. The hydroxynitrate in the precursor that did not have added $\mathrm{CO}_{2}$ decomposed before it could be converted to hydroxycarbonate. The aging-modified catalyst had a higher surface area, larger pore volume, smaller particle size, and higher catalytic activity.

\section{References}

1 Arena F, Italiano G, Barbera K, Bordiga S, Bonura G, Spadaro L, Frusteri F. Appl Catal A, 2008, 350: 16

2 Behrens M, Furche A, Kasatkin I, Trunschke A, Busser W, Muhler M, Kniep B, Fischer R, Schlögl R. ChemCatChem, 2010, 2: 816

3 Liu Y, Zhang Y, Wang T J, Tsubaki N. Chem Lett, 2007, 36: 1182

4 Koeppel R A, Baiker A, Wokaun A. Appl Catal A, 1992, 84: 77

5 Guo X M, Mao D S, Wang S, Wu G S, Lu G Z. Catal Commun, 2009, 10: 1661

6 Ma Y, Sun Q, Wu D, Fan W H, Zhang Y L, Deng J F. Appl Catal A, 1998, 171: 45

7 Hong Z S, Cao Y, Deng J F, Fan K N. Catal Lett, 2002, 82: 37

8 Shishido T, Yamamoto Y, Morioka H, Takaki K, Takehira K. Appl Catal A, 2004, 263: 249

9 Waller D, Stirling D, Stone F. Faraday Discuss, 1989, 87: 107

10 Millar G J, Holm I H, Uwins P J R, Drennan J. J Chem Soc, Faraday Trans, 1998, 94: 593

11 Li J L, Inui T. Appl Catal A, 1996, 137: 105

12 Vasserman I M, Silanteva N I. Russ J Inorg Chem, 1968, 13: 1041

13 Baltes C, Vukojević S, Schüth F. J Catal, 2008, 258: 334

14 Bems B, Schur M, Dassenoy A, Junkes H, Herein D, Schlög1 R. Chem Eur J, 2003, 9: 2039

15 夏王琼, 唐浩东, 林胜达, 岑亚青, 刘化章. 催化学报(Xia W Q, Tang H D, Lin Sh D, Cen Y Q, Liu H Zh. Chin J Catal), 2009, 30: 879

16 林胜达, 唐浩东, 吕兆坡, 刘采来, 岑亚青, 刘华章. 催化学报 (Lin Sh D, Tang H D, Lü Zh P, Liu C L, Cen Y Q, Liu H Zh. Chin J Catal), 2010, 31: 1257

17 Jun K W, Shen W J, Rao R K S, Lee K W. Appl Catal A, 1998, 174: 231 